\title{
W. H. PEARSALL, D.Sc., F.R.S.
}

A GREAT conservationist and ecologist, Professor W. H. Pearsall, D.Sc., $A_{\text {F.R.S., died on October 14th at the age of seventy-three. He was a }}$ member of the FPS Council from 1958 to 1963, and will be remembered for his great survey for the FPS of the Serengeti National Park in Tanganyika in 1956, published in ORYX the following year. Emeritus Professor of Botany at University College, London, he was a member of the Nature Conservancy from 1949.

Sir Hugh Elliott, a member of the FPS Council, who accompanied Professor Pearsall on the Serengeti Survey, sends us this tribute to him :

Others will pay tribute to the extraordinary breadth and ecological insight of his botanical knowledge, to his clarity of thought and expression, his inspiring qualities as a teacher, but to members of the FPS and readers of ORYX the name of Pearsall will always be connected with the brilliant survey of the Serengeti National Park, carried out by him at the request of the Society in the last two months of 1956, just eight years ago but already withstanding the test of time as a highlight of the Society's history. To Pearsall's lucid report of this survey is owed without any doubt the survival to this day of the still untarnished jewel of Tanganyika, and the confidence that it will remain the jewel of Tanzania and envy of the world. Re-reading the report one is chiefly struck by two characteristic features, the skilful marshalling and management of a mass of data, and the ability to assess and analyse. What the report does not perhaps so clearly reveal is the consuming energy of the man, under an exterior that would often seem exceptionally placid, his determination that nothing pertinent should be overlookedwhich to him meant that nothing should be overlooked. With it all went the true sense of humour which is really a sense of proportion. These are the qualities which distinguish the great ecologist-qualities too rarely found yet without which the battle for conservation is often lost in a mire of exaggeration, accusations and counter-accusations, the desire to score a point or reap a personal profit. It would be difficult to think of anyone less addicted to these faults, and conservation has lost in him one of its firmest friends and truest exponents.

\section{EDWARD O. SHEBBEARE} Teighty, of Edward O. Shebbeare, a member of the FPS Council from 1954 to 1958, and again from 1959 until 1964, shortly before his death. His distinguished career included thirty-two years in the Indian Forest Service, from which he retired in 1938 as Chief Conservator of Forests of (then undivided) Bengal, followed by four years as Chief Game Warden of Malaya until the fall of that country in 1942. It was due to his untiring pioneer efforts that legislation was passed for the protection of the Indian rhinoceros, which resulted in the creation of Jaldapara as a sanctuary in northern Bengal in 1941.

A rare combination of out-of-doors ruggedness (he was on two Everest and two Kanchenjunga expeditions) with an aptitude for scholarly observations of fauna and flora, Shebbeare became almost a legendary figure in eastern Asia. With an amusing disregard for convention (especially in the way of dress) he would disappear for long periods into the forests, and the result would appear in technical papers on forestry, botany and zoology. "She," as he was known to his closer friends, is now perhaps best remembered for his paper on Status of the Three Asiatic Rhinoceros (ORYX II pp. 141-149), and for his book on Indian elephants Soondar Mooni. $\quad$ E. P. GEE. 